\title{
Hélène Millet, L'Église du Grand Schisme 1378-1417
}

\section{G. Matteo Roccati}

\section{OpenEdition}

\section{Journals}

Édition électronique

URL : http://journals.openedition.org/studifrancesi/6551

DOI : 10.4000/studifrancesi.6551

ISSN : 2421-5856

\section{Éditeur}

Rosenberg \& Sellier

\section{Édition imprimée}

Date de publication : 1 septembre 2010

Pagination : 340

ISSN : 0039-2944

\section{Référence électronique}

G. Matteo Roccati, « Hélène Millet, L'Église du Grand Schisme 1378-1417 », Studi Francesi [En ligne], 161 (LIV | II) | 2010, mis en ligne le 30 novembre 2015, consulté le 08 janvier 2021. URL : http:// journals.openedition.org/studifrancesi/6551 ; DOI : https://doi.org/10.4000/studifrancesi.6551

Ce document a été généré automatiquement le 8 janvier 2021.

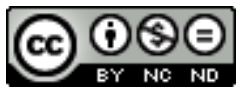

Studi Francesi è distribuita con Licenza Creative Commons Attribuzione - Non commerciale - Non opere derivate 4.0 Internazionale. 


\title{
Hélène Millet, L'Église du Grand Schisme 1378-1417
}

\author{
G. Matteo Roccati
}

\section{RÉFÉRENCE}

HÉLÈNE MILLET, L'Église du Grand Schisme 1378-1417, Paris, Picard, 2009, 272 pp.

1 L'ouvrage rassemble seize études (parues d'abord sous la forme d'articles dans les années 1985-2000) qui sont autant de chapitres résultant d'un travail de recherche cohérent, mené à partir de l'étude des événements liés au concile de Pise (1409) et de celle de leur perception par les contemporains, travail dont la logique est présentée dans l'Avant-propos. Le volume est organisé en quatre parties: I. Les assemblées du clergé, II. Grands et petits prélats sur l'échiquier bénéficial, III. Récits et témoins, IV. Schisme et prophétie. Un chapitre liminaire présente «Le Grand Schisme d'Occident vu par les contemporains: Crise de l'Église ou crise de la papauté?»; un dernier chapitre «Le grand pardon du pape (1390) et celui de l'année sainte (1400)».

2 L'ensemble est fondamental pour l'historien de l'Église, les deux dernières parties intéresseront aussi le littéraire. En particulier le ch. 10, «Qui a écrit Le Livre des fais du bon messire Jehan Le Maingre dit Bouciquaut?», propose de voir en Nicolas de Gonesse l'auteur du Livre des fais. Même si l'attribution n'a pu être confirmée (cf. D. Lalande, Mélanges Ménard, 1998), l'étude reste intéressante. Le ch. 11, «Michel Pintoin, chroniqueur du Grand Schisme d'Occident», dresse le Catalogue des documents sur le schisme insérés dans la chronique [du religieux de Saint-Denis] "in extenso" ou sous la forme abrégée et examine le réseau de relations qui a permis à Pintoin d'avoir accès aux documents officiels, parfois confidentiels, la manière dont il s'en est servi dans la rédaction de sa chronique et l'opinion sur le schisme qui s'y révèle. Dans la quatrième partie, au ch. 13, «Le cardinal Martin de Zalba ( $†$ 1403) face aux prophéties du Grand Schisme d'Occident», l'A. étudie plusieurs textes latins réunis par ce cardinal (Quedam profecia, Alique revelationes fratris Petri de Aragonia, Tractatus domini Johannis de Legnano 
secundum astrologiam, Quedam profecie seu vaticinationes, Quedam superstitiones contra Dominum nostrum); de même que dans le ch. 14, «Écoute et usage des prophéties par les prélats pendant le Grand Schisme d'Occident», elle enquête sur l'utilisation et l'impact de la littérature prophétique auprès de la hiérarchie ecclésiastique. Enfin le ch. 15 examine «Le Grand Schisme d'Occident selon Eustache Deschamps: un monstre prodigieux» (inspiré au poète par une image de la prophétie Ascende calve). Le volume est complété par l'Index des personnes et des lieux. 